\title{
The Ecumenical Significance of Karl Rahner's Mystical Transcendental Theology
}

\author{
ERIC S. DART ${ }^{*}$
}

Scattered throughout his many writings and lectures Karl Rahner frequently, directly and indirectly, addresses the topics of ecumenism and ecumenical theology. The purpose of this article is to demonstrate the connection between Rahner's mystical transcendental theology and his ecumenical theology. This is done in two successive steps. Firstly, the contours of Rahner's mystical transcendental theology are developed by tracing Rahner's foundational thought from Spirit in the World to Hearers of the Word and, finally, to his doctrine of the supernatural existential. The conversation then moves to the foundations of Rahner's ecumenical thought as it is articulated in his article Some Problems in Contemporary Ecumenism.

Keywords: Karl Rahner, transcendental, mysticism, mystical, ecumenism, ecumenical, Human questioning, spirit, ordinary mysticism, supernatural existential

\section{Introduction}

Scattered throughout his many writings and lectures, Karl Rahner frequently both directly and indirectly addresses the topics of ecumenism and ecumenical theology. As the following demonstrates, Rahner's ecumenical insights are informed by his foundational thought, which, as Harvey Eagan correctly acknowledges, is both transcendental and mystical. It should be acknowledged from the outset of the current investigation that a common understanding of the terms mystical and transcendental is not a given. Hence, while both terms will be examined in greater detail below, a few introductory comments about each term are in order to avoid confusion and misunderstanding. The term "mystical" has been interpreted and understood in a variety of ways throughout Christian history. For the purposes of the following investigation, the term "mystical" refers to an experience of God. For instance, the claim that Rahner's theology is mystical refers to his systematic reflection and investigation on the human person's experience of God. ${ }^{1}$

* Eric S. Dart, Ph.D.,Chairperson, Theology Department, Gannon University, 109 University Square Erie, PA 16541, USA, dart001@gannon.edu.

${ }^{1}$ See: Karl Rahner (ed.), Sacramentum mundi: An Encyclopedia of Theology, 6 vols. (London: Burns \& Oates, 1968), "mysticism"; Judith A. Dwyer and Elizabeth L. Montgomery, The New Dictionary of Catholic Social Thought (Collegeville, Minn.: Liturgical Press, 1994), "Mystical Theology" and "Mysticism". 
The term "transcendental" likewise runs the risk of ambiguity as it has also been used in a variety of ways. As far as a preliminary understanding, "transcendental" in the context of what follows is meant to indicate the implicit or unthematic awareness of God within human experience. As the following demonstrates more clearly, it is the unthematic awareness of God and the experience of mystery for Rahner that ultimately establishes the possibility of human transcendence; the movement beyond the concrete limits of the world towards God's holy mystery. With regard to transcendental inquiry, Rahner writes that "regardless of the particular subject-matter in which it is applied is present when and to the extent that it raises questions of the conditions in which knowledge of a specific subject is possible in the knowing subject itself." Rahner continues, "the mutual interconnection and mutual conditioning process between the subject knowing and the object known precisely as known and knowable are in themselves the object of transcendental inquiry."2 Put simply, a transcendental line of inquiry investigates the knowing subject and the object that is known and how knowledge arises via the relationship that exists between them.

As the following demonstrates, the relationship between transcendental theology and mysticism lies at the heart of Rahner's theological thought. Harvey Egan summarizes Rahner's project as follows:

Rahner's mystical theological anthropology functions as a mystical depth psychology by explicating, thematizing, strengthening, and deepening the ultimate horizon of all meaning of an experience. In short, Rahner has experienced that what concerns the entire person in his salvation, the existential significance of the facts of salvation history, cannot be made intelligible without mystical transcendental theology. ${ }^{3}$

The purpose of this article is twofold. Firstly, the following explicates Rahner's mystical and transcendental theology as it is understood by both Rahner himself and his commentators. This will be accomplished by tracing the foundational contours and development of Rahner's mystical transcendental theology from Spirit in the World to Hearers of the Word ${ }^{5}$ and

\footnotetext{
${ }^{2}$ Rahner, "Reflections on Methodology in Theology," in Confrontations I, Theological Investigations (New York: Seabury, 1974), 87.

${ }^{3}$ Harvey Egan, "Mysticism and Karl Rahner's Theology," in Theology and Discovery: Essays in Honor of Karl Rahner, S.J., ed. William J. Kelly (Milwaukee, WI: Marquette University Press, 1980), 146.

${ }^{4}$ Rahner, Spirit in the World (New York: Herder and Herder, 1968).

${ }^{5}$ Idem, Hearers of the Word (New York: Herder and Herder, 1969).
} 
finally to his doctrine of the supernatural existential. ${ }^{6}$ Secondly, this article examines Rahner's ecumenical theology in light of the transcendental and mystical contours of his thought. The examination of Rahner's Ecumenical Theology focuses on his essay, Some Problems in Contemporary Ecumenism as it succinctly expounds Rahner's ecumenical posture and thinking. The following investigation also makes some general observations regarding the significance of Rahner's ecumenical theology for contemporary ecumenism.

\section{Karl Rahner's Transcendental Mystical Theology}

Karl Rahner's transcendental turn reframes traditional Catholic dogmatic theology. Also referred to as the turn to the subject, Rahner's transcendental method led the shift in Roman Catholic theology during the mid-twentieth century away from an emphasis on manual theology and the pursuit of knowledge of isolated objects. For Rahner, human knowledge is fundamentally relational. Describing a typical understanding of knowledge, Rahner explains that, Thiswe often imagine the essential nature of knowledge after a model of a tablet on which an object is inscribed, whereby the object comes from the outside... and appears on the tablet."7 Instead for Rahner, knowledge of objects is not a static enterprise whereby an object simply makes itself known in a manner that is disassociated from the experience and prior knowledge of a subject. Instead, Rahner maintains that knowledge arises through a complex relationship and mutual conditioning between the knowing subject and the knowable object. Put another way, while knowledge of an object in itself is theoretically possible, in actuality, human knowledge is always situated within the particularity of one's own experience. Theological knowledge for Rahner is no exception. Accordingly, theological knowledge is never purified of its human element insofar as it is human persons that engage in the endeavor of making sense of the experience of God. Rahner affirms that, as with all knowledge, theology is intimately related to the experience of the human person. As such, theology cannot be understood as absolutely distinct from anthropology. Rahner explains:

As soon as man is understood as the being who is absolutely transcendent in respect of God, 'anthropocentricity' and 'theocentricity' in theology are not opposites but strictly one and the same thing, seen from two sides. Neither of the two aspects can

\footnotetext{
${ }^{6}$ See: idem, "Concerning the Relationship Between Nature and Grace," in God, Christ, Mary, and Grace, Theological Investigations (Baltimore, MD: Helicon Press, 1961), 126-33; idem, Foundations of Christian Faith: An Introduction to the Idea of Christianity Karl Rahner (New York: Crossroad, 1993).

${ }^{7}$ Idem, Foundations of Christian Faith, 17.
} 
be comprehended at all without the other. Thus, although anthropocentricity in theology is not the opposite of the strictest theocentricity, it is opposed to the idea... that it is possible to say something about God theologically without thereby automatically saying something about man and vice versa.... ${ }^{8}$

Put another way, any word about God is also a human word and, on the other hand, Rahner also maintains that as an "absolutely transcendent being" oriented towards God, that to say or know something about the human person necessarily involves saying or knowing something about God who is both the ground and the goal of human existence. Simply put, Rahner maintains that all theology is anthropology and all anthropology is theology. This insight into the relationship between theology and anthropology affords Rahner the opportunity to begin his theological inquiry from human experience and to develop an "ascending theology." The intimate relationship between theology and anthropology affords Rahner an opening to search out encounters with God in the everyday circumstances of human existence and thereby also broadening traditional ideas about the place of mysticism within the experience of the human person.

As this section demonstrates the interrelated aspects of anthropology, mysticism and transcendence ground Rahner's theology. ${ }^{9}$ Seen together, these central characteristics of Rahner's theology elucidate the relationship between the human person's experience of mystery and the meaningfulness of human existence. As a first step, Rahner investigates the transcendental knowledge of the human person as a Spirit in the world. In a second moment, Rahner explores the transcendental openness and the capacity of the human person to receive a possible revelation within history. Finally, Rahner explores the universality of God's grace through the "supernatural existential." This section will follow the development of Rahner's theology, drawing attention to its mystical and transcendental aspects.

\subsection{A Sprit-in-the-World: Transcendental Questioning}

In a first, primarily philosophical moment, Karl Rahner develops an understanding of the human person as an "embodied spirit" in Spirit in the World. ${ }^{10}$

\footnotetext{
${ }^{8}$ Idem, "Theology and Anthropology," in Writings of 1965-1967, 1, Theological Investigations (New York: Herder and Herder, 1972), 28.

${ }^{9}$ The subsequent framework of Spirit in the World, Hearers of the word and the supernatural natural existential are common reference points for understanding Karl Rahner's Theological method. The framework was initially referenced by Anne Carr. See: Anne Carr, The Theological Method of Karl Rahner (Missouia, MN: Scholar Press, 1977), 18.

${ }^{10}$ Rahner, Spirit in the World.
} 
Rahner emphasizes three aspects of human existence and human knowledge, as a spirit-in-the-world, that are particularly apropos to the present discussion regarding the mystical and transcendental aspects of his theology. Firstly, human knowledge and existence are fundamentally "othered." Secondly, human knowledge and existence are, properly understood, transcendental. Finally, human knowledge and existence are saturated with mystery.

Rahner argues in Spirit in the World that all human knowledge arises at the intersection of sensible experience of the finite world and the infinite horizon of human questioning. ${ }^{11}$ With Thomas Aquinas, Rahner upholds the identity between being and knowing whereby " $[\mathrm{k}]$ nowing is the being-present-to -self of being, and this being-present-to self is the being of the existent." 12 Further, Rahner acknowledges that the human person, as a "knowing subject possesses in knowledge both itself and its knowledge." 13 However, Rahner does not envision the identity between knowing and being characteristic of human subjectivity as an isolated and enclosed Cartesian subject. Instead, for the human person knowing and existence are fundamentally othered. Thomas Sheehan explains that:

[h] uman being is an otheredness that is always self-related and a self-relatedness that cannot exist without being othered. Since relation-to-another is the only way humans can relate to themselves, we may define human being as self-related otheredness. "Self-relatedness" means self-awareness and self-responsibility - in a word spirit. "Otheredness" means that human beings need to be affected by others - but are limited to being affected only by this-worldly corporal others. ${ }^{14}$

The human person is in possession of itself, but only in so far as the human person is in relation to an other. It is via the experience of an other that both the possibility of human questioning obtains and the possibility of deciding about one's-self is realized. However, the human person's experience is bound to the concrete world. As a spirit, the human person experiences itself as a free and responsible subject, but as a spirit-in-the-world, the human person is not as an absolute subject. Instead, the human person experiences itself as a contingent subject; that is a subject that experiences freedom and responsibility within and in relation to the concrete circumstances and limits of the world.

\footnotetext{
${ }^{11}$ Idem, Foundations of Christian Faith, 32.

${ }^{12}$ Idem, Spirit in the World, 69.

${ }^{13}$ Idem, Foundations of Christian Faith, 17-18.

${ }_{14}$ Thomas Sheehan, "Rahner's Transcendental Project," in Cambridge Companions to Religion, eds. Declan Marmion and Mary E. Hines (Cambridge-New York: Cambridge University Press, 2005), 18.
} 
The human person, as a spirit-in-the-world, is a sort of finite infinity, whereby everything can at least be a question. The human person is finite insofar as it exists and is bound to the concrete world and the human person is spirit in so far as it can transcend these limits without ever leaving the world behind. Thomas Sheehan writes that the human person is " $t]$ he perfection of finitude, a finite infinity that consists not is God's all-at-onceness but in our own finite infinity: unlimited self-synthesizing, self-mediation, and self-interpretation, unlimited responsibility, knowledge, and creativity." ${ }^{15}$ The human person's fundamental activity as a spirit-in-the-world, according to Rahner, is questioning. The question, writes Rahner, "is something final and irreducible" and every human question is at the very least an implicit question about being. ${ }^{16}$ That is, every question contains at least some trace of the metaphysical question. Anne Carr explains that the metaphysical question "is the formal articulation of the question implicit in all ordinary questioning and in fact questions both the object and the questioner." ${ }^{17}$ As such, according to Rahner, even in seemingly simple questions about particular objects, the human being unthematically encounters the silent mystery of absolute being. While Spirit in the World is primarily considered a philosophical work, Rahner's transcendental enquiry into human questioning gestures towards the mystical current that runs throughout his thought at least to the extent that Rahner imagines the human person as capable of reaching beyond one's own limits and in so doing expands one's own horizon of existence.

Borrowing from Heidegger, Rahner employs the term Vorgriff, or the pre-apprehension of being. The Vorgriff, grounds all human knowledge and conscious activity "in an unthematic but ever-present knowledge of the infinity of reality." ${ }^{18}$ As an unthematic knowledge, the Vorgriff is not an object of knowledge and it cannot be known and grasped the way a sensible object can be. However, without the Vorgriff, there would be no authentic human knowledge. Rahner writes that "the movement of transcendence is not the subject creating its own unlimited space as though it had absolute power over being, but it is the infinite horizon of being making itself manifest." ${ }^{19}$ However, the Vorgriff "is not a 'prior grasp' of God, but our limitless ability to know something about all material data." ${ }^{20}$ More precisely, the

\footnotetext{
${ }^{15}$ Ibidem, 41.

${ }^{16}$ Rahner, Spirit in the World, 57.

${ }^{17}$ Carr, The Theological Method, 66.

${ }^{18}$ Rahner, Foundations of Christian Faith, 33.

${ }^{19}$ Ibidem, 34.

${ }^{20}$ Sheehan, "The Body of Blessing" in Rahner Beyond Rahner: A Great Theologian Encounters the Pacific Rim, ed. Paul G. Crowley (New York: Rowan \& Littlefield Publishers, 2005), 28.
} 
Vorgriff is understood as the experience of the capacity for infinite being, but not the prior experience of infinite being. It is important to recognize that the index of the Vorgriff is the finitude of human person, not the infinity of God. ${ }^{21}$

Further, the human person as the one who asks the question is also involved in the question. By asking a question, the human person has already at least implicitly acknowledged the possibility of knowing something more. Thus, the human person, as the questioner, is with knowledge in so far as the question is possible but is also without knowledge in so far as the question needs be asked. Carr further explains:

The question reveals that one already has a knowledge of that which one questions, is implicitly at the goal of inquiry. At the same time, one does not totally comprehend that which is questioned. This is the paradox of the question and the point of departure for all metaphysical inquiry. ${ }^{22}$

The question demonstrates that human knowledge obtains through both the immediacy of sense meaning and the anticipation of meaningfulness. Ultimately, the transcendental nature of human knowledge and existence reveals in and through the ordinary act of human questioning that knowledge and existence are saturated with mystery. Rahner summarizes:

Basically, he is always on the way. Every goal that he points to in knowledge and in action is always relativized, always a provisional step... He is spirit who experiences himself as spirit in that he does not experience himself as pure spirit. Man is not the unquestioning and unquestioned infinity of reality. He is the question which rises up before him, empty, but really and inescapably, and which can never be settled and never be adequately answered by him. ${ }^{23}$

Simply put, human knowing and existing obtain through the complex coadunation between an infinite openness to mystery and the radical limits of bodily existence.

In sum, the human person, in the activity of questioning, transcends the concrete limits of sensible data through the pre-apprehension of the infinite horizon of possibility and demonstrates that the human person is in the business of making sense of things; putting together meaning and experience. The activity of transcendence, as it is outlined in Spirit in the World, gestures towards Rahner's concern for bringing mystical experience

\footnotetext{
${ }^{21}$ Ibidem, 28-29.

${ }^{22}$ Carr, The Theological Method, 67.

${ }^{23}$ Rahner, Foundations of Christian Faith, 32.
} 
to reasonable expression and anticipates his desire to uncover an "ordinary mysticism." ${ }^{24}$ Describing ordinary mysticism, Rahner explains:

If we wanted to describe as 'mysticism' this experience of transcendence in which man in the midst of ordinary life is always beyond himself and beyond the particular object with which he is concerned, we might say that mysticism always occurs, concealed and namelessly, in the midst of ordinary life and is the condition of the possibility for the most down-to-earth and most secular experience of ordinary life. ${ }^{25}$

For Rahner, an identity exists between mysticism and transcendence whereby both designate an experience of God. To be clear, Rahner is not interested in minimizing the importance of the mystics in the extraordinary sense. Instead, Rahner's concern is to uncover the possibility and sight of mystical experience within the ordinary circumstances of everyday life. Put another way, Rahner's intention is to investigate and call attention to the often neglected and overlooked transcendental encounters with God's holy mystery in the midst of ordinary life.

\subsection{Hearers of the Word: Transcendental Openness}

Rahner's next work, Hearers of the Word, continues to develop the foundational thought that he began with Spirit in the World. In Hearers of the Word Rahner establishes the possibility of the human person receiving a revelation. Michael Purcell explains:

What Hearers of the Word does to Spirit in the World is actually to change its declension. The nominative of speaking in the question with its immediacy and intransitivity becomes the accusative of hearing which is always mediate and transitive. The solitary subject seeking within itself the transcendental source of its question becomes the one who discovers himself always and If thisalready the subject of an address. ${ }^{26}$

In Hearers of the Word, the concept of the human person as an embodied spirit or spirit-in-the-world is expanded beyond the dynamic activity of hu-

\footnotetext{
${ }^{24}$ See: Rahner, "Experience of the Holy Spirit" in God and Revelation Theological Investiagtions (New York: Crossroad, 1983); idem, "Experience and Transcendence from the Standpoint of Christian Dogmatics," in God and Revelation, Theological Investigations (New York: Crossroad, 1983); idem, "Mystical Experience and Mystical Theology," in Jesus, Man, and the Church, Theological Investigation (New York Crossroad, 1981).

${ }^{25}$ Rahner, "Experience of the Holy Spirit," 197.

${ }^{26}$ Michael Purcell, Mystery and Method: The Other in Rahner and Levinas (Milwaukee, WI: Marquette University Press, 1998), 22.
} 
man questioning and coquestioning and receptive hearing are only possible within history. As Jessica Murdoch correctly observes, "[t]he Rahnerian Subject is inescapably historical." ${ }^{27}$ Hearers of the Word affirms the significance of human historicity and further develops the hermeneutic process that Rahner began in Spirit in the World. In Hearers of the Word, Rahner's purpose, observes Anne Carr, "is to show that the question of the human knower reveals not only the openness of and hiddenness of being but also the historicity and freedom of human existence." 28

In Hearers of the Word, Rahner investigates the process of becoming; how the human person comes to self-realization and self-actualization in and through the world, time, and space. History and the world are the inescapable existential conditions whereby the human person "even as doer and maker is still receiving and being made." ${ }^{29}$ As such, should a possible revelation occur and be heard, it must be a historical revelation, because, if it is to be received and responded to by a human person, revelation must be given in a way that is congenial to the experience of the human person. Rahner's understanding of the human person as a hearer of a possible revelation reimagines the traditional concept of potentia oboedientialis (obediential potency) in Christian philosophy. Rahner explains that:

Man is the existent thing who must listen for an historical revelation of God, given in his history and possibly in human speech... Man is one who listens in his history for the word of the free God. Only thus is he what he must be. Metaphysical anthropology has thus reached its conclusion when it has comprehended itself as the metaphysics of potentia oboedientialis for the revelation of the supernatural God..$^{30}$

As the entity who listens for a possible revelation in history, the human person is also that entity who must interpret and appropriate this possible word from God. The transcendental and historical nature of the human person affirms that the human being is a hermeneutic being and as such is fundamentally interpretive.

\footnotetext{
${ }^{27}$ Jessica M. Murdoch, "Overcoming the Foundationalism/Nonfoundationalist Divide: Karl Rahner's Transcendental Hermeneutics," Philosophy \& Theology 22, no. 1-2 (2010): 378.

${ }^{28}$ Carr, The Theological Method, 88; Rahner defines historicity as "that characteristic and fundamental determination of man by which he is placed in precisely as a free subject, and through which a unique world is at his disposal, a world which he must create and suffer in freedom, and for which in both instances he must take responsibility."; Rahner, Foundations of Christian Faith, 41.

${ }^{29}$ Ibidem, 42.

${ }^{30}$ Idem, Hearers of the Word, 161-62.
} 
Hearers of the Word establishes the significance and mediating function of one's place in history with respect to revelation. However, the human person's spatiotemporal and socio-cultural position does not merely provide the "lens" through which the human person interprets revelation; instead, the historical reality of the human person provides the possibility of receiving and interpreting. Rahner maintains that radical immediacy of God and the mediation of God's self-communication are not opposed to one another and are not mutually exclusive alternatives. Instead, Rahner argues that it is the historical-categorical dimension of human existence that makes an immediate relationship to God possible for the human person. ${ }^{31}$ Thus the "ordinary mysticism" for which Rahner argues, acknowledges that any encounter with God is one that can be characterized as a sort of 'mediated immediacy.'

\subsection{Supernatural Existential: The Proximity of God's-self}

The third step in the development of Rahner's foundational thought and theology is what he terms the "supernatural existential." ${ }^{2}$ The supernatural existential marks a shift in Rahner's thought towards concerns that are explicitly and primarily theological. The doctrine of the supernatural existential develops in relation to the debate over the relationship between nature and grace in Roman Catholic theology. ${ }^{33}$ The transcendental capacity of the human person that is directed towards and also elicits the desire for God owes itself to the supernatural existential; "'supernatural' because it is the initial step in God's gratuitous self-communication, and 'existential' because, abidingly present to all, it permeates the totality of life." ${ }^{34}$ The supernatural existential ordains and alters the "nature" of the human person, directing the human person towards a supernatural end. Drawing upon the philosophical insights developed in both Spirit in the World and Hearers of the Word, Rahner argues against the extrinsicism of the Scholastic understanding of grace on the one hand and the position of nouvelle théologie that proposes an "unconditional reference of nature to grace" on the other

\footnotetext{
${ }^{31}$ Idem, "Experience and Transcendence," 179.

32 The term existential is defined as "a permanent determination penetrating all elements of human existence, which reveals its meaning and structure, characterizing the human being before she engages in any free action." Ethna Regan, "Not Merely The Cognitive Subject: Rahner's Theological Anthropology," in Rahner: Theologian for the Twenty-First Century, eds. Pádraic Conway and Fáinche Ryan (Oxford-New York: Peter Lang, 2010), 127.

${ }^{33}$ Rahner, "Nature and Grace," in More Recent Writings, Theological Investigations (Baltimore, MD: Helicon Press, 1966), 166-69.

${ }^{34}$ Stephen Duffy, "Experience of Grace," in The Cambridge Companion to Karl Rahner, eds. Declan Marmion and Mary E. Hines (Cambridge-New York: Cambridge University Press, 2005), 34 .
} 
hand. ${ }^{35}$ Rahner's abiding concern is to articulate and defend the universal saving will of God while also protecting the gratuitousness of God's loving and free gift of God's-self.

Rahner observes that "human beings should be able to receive this love which is God: they must have a real congeniality for it. They must be able to accept it... as people who have room and scope, understanding and desire for it." ${ }^{36}$ Geffrey Kelly explains:

Rahner uses his theological construct of the supernatural existential to indicate that human nature with its openness to being - or, to borrow a traditional scholastic term, "obediential potency" for fulfillment in being - is transformed through the advent of God's unending presence. In such a way, a person's concrete existence or the "existential" becomes ordered to God and touched irrevocably by God. ${ }^{37}$

Hence, the supernatural existential alters the natural transcendental horizon of the human person and reorients it towards the supernatural horizon of God's grace. This reorientation towards the supernatural horizon, however, "is not the object of an individual, a posteriori and categorical experience of man alongside of other objects of experience." ${ }^{38}$ Instead, the human person, before any kind of conceptual or thematic experience and expression, is tacitly aware that he or she is fundamentally "the event of God's absolute self-communication." 39

The initial offer of supernatural fulfillment through God's loving and gracious gift of God's-self, not only reorients the transcendental horizon of the human person, but also reorients human subjectivity. However, as the event of God's absolute self-communication, the human person, as a subject, freely accepts or rejects God's gracious offer. Put succinctly, the supernatural existential, as God's initial offer, is the condition of possibility for accepting or rejecting God in the concrete circumstances of human existence. Rahner explains that "[i]n order to be able to accept God without reducing him, as it were, in this acceptance to our finiteness, this acceptance must be borne by God himself. God's self-communication as offer is also the necessary condition which makes its acceptance possible.”40

\footnotetext{
${ }_{35}$ Patrick Burke, Reinterpreting Rahner: A Critical Study of His Major Themes, 1st ed. (New York: Fordham University Press, 2002), 56.

${ }^{36}$ Rahner and Geffrey B. Kelly, Karl Rahner: Theologian of the Graced Search for Meaning, The Making of Modern Theology (Minneapolis: Fortress Press, 1992), 112.

${ }^{37}$ Ibidem, 44.

${ }^{38}$ Rahner, Foundations of Christian Faith, 129.

${ }^{39}$ Ibidem, 126.

${ }^{40}$ Ibidem, 128.
} 
In sum, supernatural existential is the "secret ingredient" of transcendent experience that reveals itself in the mystery of human existence and in everyday life. As a consequence, this supernatural orientation allows for the human person to be God's partner. The free and gracious offer of God elicits and provides for the possibility of a free and gracious response to the mystery that permeates the whole of human existence. Rahner's understanding of the supernatural existential explains that the human being's openness to God's grace is not a mere non-repugnance and instead, claims that the human person has a real affinity for grace; the human being has a real potency for God's grace. ${ }^{41}$

\subsection{Rahner and Mystery}

As the above demonstrates, in and through transcendental experience the human person, in Rahner's theology, is irrevocably oriented towards mystery. ${ }^{42}$ Mystery in one way or another runs through Rahner's entire transcendental project as its animating source and goal. To briefly summarize, 1) as a spirit-in-the-world, human questioning is only possible because of the human person's pre-apprehension of being; 2) the possibility of the human person as the potential recipient of a possible revelation is only possible because of the human person's receptivity to mystery; and 3) the supernatural existential articulates the human person's radical proximity to God's holy mystery through God's initial gracious offer of God's-self. As Rahner observes, theology is properly understood as "the 'science' of mystery as such. ${ }^{43}$ The experience of mystery is the thread that draws together Rahner's transcendental and anthropological concerns. Rahner recognizes that the existential situation of the human person is saturated with the mystery of radical "otherness". This existential situation is such that the human person's limitless hunger and thirst for knowledge and existence owes itself to an initial and unthematic encounter with God as the absolute mysterious other. The encounter with mystery lures the human person towards the necessity of interpretation in order to appropriate the infinite meaning and significance of existence within the experience of the limits of the concrete world.

However, as Rahner correctly recognizes, a distinction must be made between the original transcendental experience and the objective articulation of the transcendental experience. Declan Marmion explains:

\footnotetext{
${ }^{41}$ Rahner and Kelly, Karl Rahner: Theologian, 114.

${ }^{42}$ Rahner, "The Concept of Mystery in Catholic Theology," in More Recent Writings, Theological Investigations (New York: Seabury Press, 1974), 49.

${ }^{43}$ Idem, "Reflections on Methodology," 102.
} 
A theology that does not acknowledge this dimension of mystery, the reductio in mysterium or, more precisely, a 'reductio in mysterium Dei', of theological propositions, has, in [Rahner's] view, failed its true mission. It has failed to recognize the analogical nature of such theological propositions and remained stuck on the conceptual level. ${ }^{44}$

Put another way, a theology that is not grounded in and that does not adequately express and embody the transcendental mystical experience of God's mediated immediacy does not fulfill its purpose. Rahner clarifies the relationship between transcendental experience and mysticism and the lucid theological expression of such experiences when he writes:

It seems to me... to be the task of Christian theology as a whole and the Christian theology of mysticism in particular to show and to render intelligible the fact that the real basic phenomenon of the mystical experience of transcendence is present as innermost sustaining ground... in the simple act itself of Christian living in faith, hope, and love, that such... implicit transcendence into the nameless mystery known as God is present by grace in the very believing, hoping, and loving... ${ }^{45}$

Accordingly, for Rahner, any theology worth its salt must be both transcendental and mystical to the extent that it adequately (not perfectly) expresses the presence of God in the living experience of human persons. Further, Rahner is armament that one ought to not confuse the mystical experience of transcendence with its objective expression. However, objective expressions that are not rooted in the experience of faith, hope, and love or expressions that do not express faith, hope, and love, are in both cases not properly theological.

\section{Karl Rahner's Mystical Transcendental Theology and Ecumenism}

The above describes Rahner's transcendental mystical theology and his concern for making sense of the human person's relationship to mystery. As the following argues, the interrelated mystical, anthropological, and transcendental themes that run throughout Rahner's work not only inform his ecumenical thought but, also have the potential to inform ecumenical activity and thought in general.

${ }^{44}$ Declan Marmion, "Some Aspects of the Theological Legacy of Karl Rahner," in Karl Rahner: Theologian for the Twenty-First Century, eds. Pádraic Conway Ryan and Fáinche (New York: Peter Lang, 2010).

${ }^{45}$ Rahner, "Experience and Transcendence," 176. 
The purpose of ecumenism is somewhat obvious and self-evident; the full unity of Christ's Church or Koinonia. The 1991 Canberra Statement of the World Council of Churches describes the Koinonia of the church as follows:

The unity of the church to which we are called is a koinonia given and expressed in the common confession of the apostolic faith; common sacramental life entered by one baptism and celebrated together in one eucharistic fellowship; a common life in which members and ministries are mutually recognized and reconciled; and a common mission witnessing to the gospel of God's grace to all people and serving the whole of creation. ${ }^{46}$

Further, "The goal of the search for full communion is realized when all churches are able to recognize in one another the one, holy, catholic, and apostolic church in its fullness." ${ }^{47}$ The Koinonia of the Church is manifest when its nature and identity as one, holy, catholic, and apostolic are brought to expression in and through the lived activities of Leitourgia (Worship), Martyria (Witness), and Diakonia (service). Unfortunately, the pursuit of the unity of the church has disproportionately favored an emphasis on the objective differences between Christian communities. As the following demonstrates, Rahner's ecumenical theology provides good reasons for challenging the prominence of objective expressions and formulations within ecumenical activity.

Before turning to Rahner's ecumenical theology, a few summarizing comments are in order. Firstly, as the preceding discussion has demonstrated, Rahner's theology holds in tension the realities of unity and difference. This is especially true of human experience and its subsequent interpretation including mystical transcendental experience. As James Bacik observes, Rahner frequently uses dialectic pairs of seemingly opposite realities and brings them into relationship with one another forming a unity-in-difference. For instance, individuality is realized in community; transcendence towards the infinite is experienced in and through finite realities; knowledge is possible only in relation to what cannot be known. ${ }^{48}$ Secondly and in relation to Rahner's logic of unity-in-difference, there is a strong hermeneutic

\footnotetext{
${ }^{46}$ World Council of Churches, "The Unity of the Church as Koinonia: Gift and Calling," in The Ecumenical Movement: An Anthology of Key Texts and Voices, ed. Michael Cope Brian E. Kinnamon (Geneva-Grand Rapids, Mich.: WCC Publications-W.B. Eerdmans Pub., 1997), 124.

${ }^{47}$ Ibidem.

${ }^{48}$ James J. Bacik, Humble Confidence: Spiritual and Pastoral Guidance from Karl Rahner (Collegeville, Minnesota: Liturgical Press, 2014), 13-14.
} 
current that runs throughout theology. Human existence is fundamentally interpretive, because existence and experience are always othered in the world. The experience of the particularity and finiteness of the world and the unifying experience of God's grace form the foundation of the hermeneutic process for the human person. Anne Carr writes:

[Rahner's hermeneutic circle] consists of a view of man and his world, or nature, as already in dialectical unity (and thus abiding diversity) with grace, the self-communication of God in being and knowledge. Duality in unity is what man experiences in his being and activity and it is first opaque. But upon reflection, it opens to reveal the implicit differentiations which are the foundation upon which experience rests, the unthematized but conscious structures of existence. ${ }^{49}$

Leo O'Donovan maintains that to answer any "theological question adequately one must approach it from both a transcendental and an historical perspective." ${ }^{50}$ The same holds for ecumenical questions which must be theological. "[F]aith is itself a human interpretation of human experiences, a lived, existential understanding of what human being already is and knows" in and through the uniqueness and particularity of space and time. ${ }^{51}$

\subsection{Rahner's Ecumenical Theology}

Throughout his theological career it is evident that Rahner increasingly devoted more time and energy to the topic of Ecumenism and Church unity. In fact, one of his final publications, Unity of Churches: An Actual Possibility was written shortly before his death in 1984. In 1972, Rahner published the essay entitled, Some Problems in Contemporary Ecumenism. ${ }^{52}$ In this article, Rahner, identifies two theses that he believes ought to ground ecumenical theology and discussion. Firstly, Rahner suggests that ecumenism and ecumenical discussion should begin with the presupposition that ecumenical partners recognize the presence of God's justifying grace in one another's church. Second, Rahner believed that ecumenical theology needed to be worked out from the historical diversity of particular churches.

${ }^{49}$ Carr, "Theology and Experience in the Thought of Karl Rahner," in The Journal of Religion 53, no. 3 (1973): 365.

${ }^{50}$ Leo J. O'Donovan, "Orthopraxis and Theological Method in Karl Rahner," in Proceedings of the Thirty-Fifth Annual Convention: The Catholic Theological Society of America, ed. Luke Salm (1980), 49.

${ }^{51}$ Sheehan, "The Body of Blessing," 25.

52 Rahner, "Some Problems in Contemporary Ecumenism," in Ecclesiology, Questions in the Church, The Church in the World, Theological Investigations (New York: Seabury, 1976). 
The foundation for ecumenical theology, according Rahner, is the justifying grace. Rahner explains:

The ultimate basis for ecumenical theology is the unity, apprehended in hope, of a belief in justifying grace which already exists and is identical on both sides, yet, which, so far as theology is concerned together with the credal formula which gives it conceptual expression, is still in the process of being achieved. ${ }^{53}$

Here Rahner draws attention to the distinction between experience and the objective expression of experience. For the Christian the mystical experience of God's justifying grace that is experienced in and through one's own Christian community and the expression of God's grace are not identical. Every encounter with God and its subsequent reflection takes place within and is shaped by the unique context of a particular time and place. Thus, it should be expected that within the existential diversity of human experiences there would arise a diversity of interpretations regarding the revelation of God's absolute mystery. This is because any objective expression of God's absolute mystery is always a limited expression; it never fully encapsulates or exhausts what it seeks to express. The human always knows more in experience than can be brought to expression. Rahner acknowledges that "[a]ll of us 'know' in the Spirit of God something more simple, more true, and more real than that which we are capable of knowing and expressing in the dimension of our theological concepts." ${ }^{4} 4$ The claim that all Christian knowledge is animated by the Spirit of God is not a clever tactic to gloss over the real concrete differences between separated Christians. Instead, this distinction between faith as it is experienced and faith as it is objectified needs to be taken into consideration, but not in such a way as to prioritize objective expression of the experience of God's grace over the actual mystical experience of God's grace. Rahner writes:

A necessary prior condition for [ecumenical] dialogue is the distinction that must be drawn between the basic and ultimate faith which is present in the midst of our lives through the Spirit of God on the one hand and the faith of the Church on the other which is expressed in objective concepts. ${ }^{55}$

Again, Rahner is not suggesting that the concrete/objective differences that divide Church are superfluous, but he does suggest that such objective formulations ought not receive undo attention and consideration within ecu-

\footnotetext{
53 Ibidem, 248.

${ }^{54}$ Idem, "On the Theology of Ecumenical Discussion," 37.

${ }^{55}$ Ibidem, 40.
} 
menical discussion. Differences in the concrete manifestations of Martyria, Diakonia, and Leitourgia are real and significant and demand attention, but such differences are not as fundamental as the unifying reality of God's justifying grace.

Rahner's transcendental reduction, when applied to the lived expression of separated churches, reorients the too often held presupposition that ecumenical activity is effectively achieved through reconciling objective differences between divided Christians. Rahner's transcendental reduction shifts emphasis away from prioritizing reconciling difference towards an emphasis on discovering the unique manner through which God's grace is manifest and experienced in and through the Christian other and his or her community. Rahner writes:

When we Christians, projecting our ideas beyond confessional boundaries, credit one another with the presence of the Holy Spirit of grace, then manifestly what we are saying is... that the ultimate most interior 'testimonium spiritus' is present in all, or at least must be presumed to be present, that all of us are endowed with the 'illustratio et inspiratio' of the Spirit..., with the wordless groanings and utterance of 'Abba' of the Spirit within the depths of our hearts, with anointing of the Spirit spoken of by John which instructs us - all of this is present even though this innermost reality of the Spirit and faith is objectified and interpreted differently in terms of words and ideas between the individual confessions. ${ }^{56}$

Beginning with God's justifying grace through the presence of the Holy Spirit as the animating principle of both one's own church as well as that of the ecumenical other establishes a relational model built upon a sort of confident modesty.

The church is the manifestation of God's grace within history and as such has a transcendental and historical structure. Rahner writes:

As an historical and social entity, the Church is always and unchangeably the sign which brings with it always and inseparably what it signifies. As with Christ the distinction between his Godhead and his humanity remains without confusion though they are inseparable, sign and reality, manifest historical form and Holy Spirit, are not the same in the Church, but as in Christ, are not separable anymore either. The Church is the official presence of the grace of Christ in the public history of the one human race. ${ }^{57}$

\footnotetext{
${ }^{56}$ Ibidem, 37.

${ }^{57}$ Idem, "The Church and the Sacraments," in Inquiries (Herder and Herder, 1964), 201.
} 
Any visible manifestation of Christ's church is marked by particularity. Like the human person, the church is unavoidably historical. The Church only realizes its nature and purpose, as the presence of God's grace within the particularity of its spatial, temporal, cultural, and societal boundaries. Hence, the historicity of church is the inescapable context in which it "becomes" in and through the freedom and responsibility of its members. Put another way, the nature of the Church (the visible sign of God's grace) is manifest through the visible identity of the Church (one, holy, catholic, and apostolic) in the Church's lived activity (Martyria, Diakonia, Leitourgia). As the people of God, the historicity of human experience is a significant aspect that needs to be considered with regards to ecumenical relationships between separated churches.

Rahner maintains that any ecumenical theology of the future must be worked out within the particularity of individual churches. This includes the unique history of the churches. Rahner writes:

That which most of all constitutes ecumenical theology is the theology of the future, which has to be worked out by all the Churches each from its own point of departure as already laid down by its past history. ${ }^{58}$

Informed by his mystical transcendental theology, Rahner recognized that a truly ecumenical theology must come to terms with history, not try to overcome it. Put differently, Rahner recognized that the unity of the church would not be established by reconciling theological propositions. Instead, Rahner understood that the success of ecumenism was ultimately proportionate to the courage of dialogue partners to acknowledge the justifying grace of God in the ecumenical other and the willingness of dialogue partners to come to terms with their historical context for good and for ill.

\section{Conclusion}

Karl Rahner's ecumenical theology logically flows from his mystical transcendental theology. As the above has demonstrated, Rahner's attentiveness to both the unifying reality of justifying grace and complexities of historical difference provide important guidance for contemporary ecumenical theology. In some sense, Rahner's ecumenical theology turns contemporary ecumenism on its head through his emphasis on justifying grace as more original and unifying that the historical differences that divide Christians. This conviction carried through Rahner's later theological writings and is most evident in Unity of the Churches: An Actual Possibility. Rahner and Fries conclude Unity of Churches with the following:

${ }^{58}$ Idem, “Some Problems in Contemporary Ecumenism,” 252. 
The indispensable prayer to the Lord of the Church for the unity of Christians and of the churches must not be an alibi for human sloth and lack of imagination; instead, it must be the ever-new motivation to an attitude and mind-set which is expressed in the rule of Taizé: "Never be content with the scandal of separated Christendom. Have the passion for the unity of the body of Christ." ${ }^{59}$

${ }^{59}$ Heinrich Fries and Karl Rahner, Unity of the Churches: An Actual Possibility (PhiladelphiaNew York: Fortress Press-Paulist Press, 1985), 140. 